\title{
The Influence of Project Management Knowledge of Academics on the Success of University Research Projects
}

\author{
Ahmed Ibrahim* Ding Yong \\ School of Management, Hefei University of Technology, 193 Tunxi Road, Hefei 230009, China
}

\begin{abstract}
Literature shows that Project Management Knowledge is critical for many industries to achieve Project success, which has steadily increased and has become indispensable in many industries. This study investigated the influence of Project Management knowledge of Academics to the success of academic research projects. The hypothetical model was adopted from the PMBOK guide framework.A survey questionnaire of academics (University researchers) performed in universities in the city of Hefei, China was used to obtain empirical data. The results revealed a positive significant relationship between Project Management Knowledge Areas and Project Success. Importance-Performance Analysis (IPA) was also carried out to enable the researchers and managers to understand the contribution of individual Project Management Knowledge Areas. The work has numerous contributions to the body of knowledge and highlights Project Management Knowledge Areas critical for academics to achieve project success.
\end{abstract}

Keywords: Project management; Project Success; Project Management Knowledge Areas; Academics; Importance-Performance Analysis.

DOI: $10.7176 / E J B M / 11-15-15$

Publication date:May $31^{\text {st }} 2019$

\section{Introduction}

The field of Project management has come a long way from what it used to be. Previously it had insufficient coverage as a research field (Davis, 2014) but has now developed into a discipline alongside other management functions which have seen growth in research literature(Mir \& Pinnington, 2014). There is no doubt that companies seeking competitive advantage are utilizing project management to keep achieving business success. Companies are seeing the payoff from investing resources to developing Project management expertise as this is translating to lower cost, stakeholder satisfaction, and higher competitive advantage so much that it was instrumental in lifting companies from recession(PMI, 2010).

For over 50 years now, Project Management has been imperative in the execution of complex activities. Project Management encompasses Portfolio Management and Program Management and it virtually cuts across all industries. It has a wide industrial application from industrial manufacturing, Architecture, Engineering and Construction, Utilities, Oil and Gas, Chemicals, Aerospace and Defense, Mining and Metals, Pharmaceuticals, Pulp and Paper, Satellite TV, Information Technology industry, Financial Services, Health, Telecom, Transport and logistics(APM, 2016; Gale, 2009; PMI, 2010). Project Management encompasses Portfolio Management and Program Management and it virtually cuts across all industries.

There is a lot of literature in relation to these industries especially the construction industry but the literature regarding Project Management in the Education Industry is largely scanty. The Education sector especially universities has made a lot of contribution in the field of Project Management, especially since it is a center for training students of project management and equipping them with the necessary skills (Pant \& Baroudi, 2008). A key role of universities is enabling academics or university researchers to carry out research projects. In fact, University-Industry collaborations are huge resources/assets to companies which are strategic in fulfilling company goals. Academics carry out research projects which are self-sponsored, institution sponsored, Government sponsored, and industry-sponsored or even funded by private individuals or groups. It is evident that numerous research projects are carried out at different scales which begs the question, how are such projects managed. (Sanders \& Ireland, 2007) Kerzner opines that irrespective of the industry type in the pursuit of excellence at the core, Project Management follows common practices/behaviors, even though certain Project Management practices will be unique depending on the industry which is to say that Universities which are laden with research projects at different capacities share the same practices and behaviors as other industries which have really benefitted from Project Management practices. This raised the curiosity as to which Project Management practices are employed by academic professionals or university researchers in managing their research projects and to what extent they are utilized and finally assessing which ones have a bearing on achieving project success.

Academic researchers are indeed subject matter experts in their various fields but then the question still remains if that alone is enough to effectively and efficiently manage research projects considering the complexity and interdisciplinary nature of some projects. Having knowledge of the subject matter is key but is it sufficient to carry out research projects or is there a need for at least basic knowledge of project management practices. This research does not seek to check if academics strictly adhere to existing Project Management practices of Project 
Management professionals but rather understand their system of managing research projects and how much success has been achieved by doing so with a view to proposing which practices could be utilized from Project Management practices by professionals of various industries since in-depth surveys carried over the years has left no doubt as to the value that Project Management delivers to different organizations and industries. A survey by PMI(PMI, 2017) on how professionals strive to advance the conversation around the value of Project Management considered over 3234 Project Management professionals from more than 18 different industries and 200 senior executives across the globe, to find out the trends in the way organizations manage projects. The PMI survey concluded that when organizations implement project, program, and portfolio management practices, projects are more successful (PMI, 2017). Furthermore, organizations recognize the strategic value of project management, recognizing the connection between project implementation and business success. Projects are meeting initial goals and business intent and being completed within budget. A similar survey by Project Management Institute(PMI) of over 5400 Project Management professionals led to the conclusion that understanding and implementing proven Project Management practices led to greater success and less waste(PMI, 2018) and that effective Project Management is key to implementing organizational strategy.

So what Project Management practices are employed by University researchers in other to achieve project success? The objective of identifying factors or practices that impact the success or failure of a project inspires this empirical study of the influence of Project Management Knowledge on project success. This study aims to explore how PMBOK Project Management Knowledge affects Project Success of university researchers in academia. This study strives to provide imperative information as to what Project Management practices are used by university researchers to achieve project success in Universities in China.

To demonstrate the impact of PMBOK on Project success in the University, the researchers designed and carried out a survey in 4 Universities in Hefei City, China. An analysis using regression analysis was carried out.

\section{Conceptual Framework}

\subsection{Project management knowledge areas}

PMBOK guide identifies 10 distinct knowledge areas: Integration, Scope, Time, Cost, Quality, Human Resource, Communication, Risk, Procurement and Stakeholder-based on 47 Project Management processes in 5 Project Management process (Project Management Institute, 2013). Though detailed as discrete elements, in reality, they are repetitive and actually overlap and interact(Project Management Institute, 2013). (Chou, Irawan, \& Pham, 2013)used eight knowledge areas to carry out a multinational study of the contribution of PMBOK to the success of construction engineering projects. (Ling et al., 2008) used nine components to carry out research on the significance of Project Management knowledge to project performance. Each PM knowledge area (PMKA) has certain Project Management processes so as to produce the required outcome, it further utilizes certain tools and techniques to process certain outputs. (Ling et al., 2008) and Chou et al. (2013) used the management techniques, tools and skills (TTS) as PMBOK indicators. The researchers decided to use PMKA individual processes as the indicators for this research similar to the classification made by (Morteza \& Kamyar, 2009)this is because unlike surveys which mainly target individuals with a certain level of knowledge of Project Management practices in the construction industry, most University researchers do not have a deep understanding of the PMBOK knowledge areas and the corresponding indicators of Project Management techniques, tools and skills(TTS) therefore using technical words would make this survey incomprehensible as such the researcher structured the indicators of PMBOK knowledge areas along the forty-seven Project Management processes thereby making it simpler for responders to understand the questionnaire. The Project Management knowledge Areas investigated in this study include all ten components. Table 1. represents the ten knowledge areas and the corresponding processes chosen as indicators. 
Table 1. Project Management Knowledge Areas and corresponding Indicators

\begin{tabular}{lll}
\hline Construct & Indicator & Label \\
\hline Integration & Resource allocation & I1 \\
& Trade-offs between competing goals & I2 \\
Integration of project management knowledge areas & I3 \\
Scope & Task Identification & S1 \\
& Task Definition & S2 \\
Scope control & S3 \\
Time & Timely task completion & T1 \\
& Task order & T2 \\
& Task duration per phase & T3 \\
Timely completion of the entire task & T4 \\
Cost & Cost planning & C1 \\
& Cost estimation & C2 \\
& Budgeting & C3 \\
Quality & Cost control & C4 \\
& Quality requirements and /or standards & Q1 \\
Human Resource & Meet and verify project requirements & Q2 \\
& Monitor and record results, suggest improvements & Q3 \\
& Staffing & HR1 \\
& Team members cooperation & HR2 \\
Communication & Project Team Training & HR3 \\
& Project team performance appraisal & HR4 \\
& Information collection and distribution & COM1 \\
Risk & Project progress report & COM2 \\
& Manage Stakeholders & COM3 \\
Procurement & Risk Identification & R1 \\
& Risk Analysis & R2 \\
Stake Holder & Risk Management plan & R3 \\
& Risk control & R4 \\
& Procurement plant & P1 \\
& Execute procurement plan & P2 \\
& Managing project purchasing relationships & P3 \\
& Identifying Stakeholders & SH1 \\
& Develop stakeholder management strategies & SH2 \\
\hline & &
\end{tabular}

2.2 Project management knowledge areas and its relationship to project success.

The PMBOK guide which is one of the foremost literature of the Project Management profession is quite comprehensive. It encompasses the project management process groups, knowledge areas, and their corresponding processes and the concept of Project Success. Nonetheless, even with the PMBOK and ever-growing amount of literature, there are few empirical studies that have actually explained the relationship between Project Management knowledge areas and project success. This research study aims to assess the project management knowledge of university researchers and further identify the key knowledge areas that contribute to project success. The project management knowledge of University researchers will be classified under PMKA whereas project success will be viewed within the context of the academia i.e. how the university researchers view Project Success. In fact, Project Management literature demonstrates that there is a positive relationship which exists between Project Management knowledge areas and Project Success(PMI, 2013). From such literature, it can be stated that the individual Project Management knowledge Areas has the potential to contribute to Project Success while at the same time interacting with each other as evidenced by (Chou et al., 2013). The argument stated above that Project Management knowledge contribute to Project Success while being able to interact with each other leads us to make the following hypotheses:

Hypothesis 1(H1), Project Management knowledge Areas has a direct positive association with Project Success.

After considering previous empirical studies and Project Management literature such as Project Management Body of Knowledge (PMBOK) guide there is evidence to support a positive relationship between Project Management Knowledge Areas and Project Success, these hypotheses look into the individual Project Management Knowledge Areas contribution to Project Success.

The Hypotheses listed below will be tested: 
Table 2. List of Hypotheses

H2 Project Integration Management (PIM) has a positive direct association with Project Success

H3 Project Scope Management (PSM) has a positive direct association with Project Success

H4 Project Time Management (PTM) has a positive direct association with Project Success

H5 Project Cost Management (PCM) has a positive direct association with Project Success

H6 Project Quality Management (PQM) has a positive direct association with Project Success

H7 Project Human Resource Management (PHRM) has a positive direct association with Project Success

H8 Project Communication Management (PCOM) has a positive direct association with Project Success

H9 Project Risk Management (PRM) has a positive direct association with Project Success

H10 Project Procurement Management (PPM) has a positive direct association with Project Success

H11 Project Stakeholder Management (PSHM) has a positive direct association with Project Success

In accordance with the propositions and subsequent hypothesis generated a hypothetical model is given in Fig.1

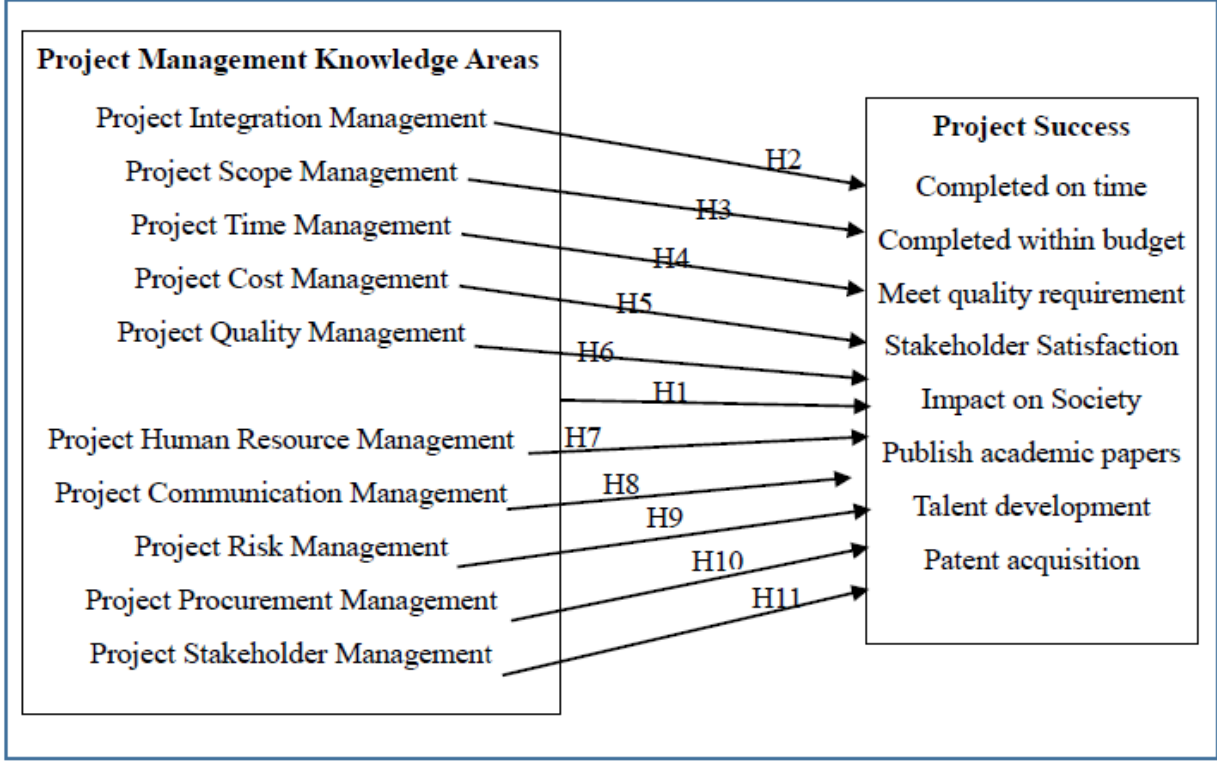

Fig. 1. Hypothetical model

\subsection{Project success}

Project Management as a profession means that the application of knowledge, processes, skills, tools, and techniques can have a significant contribution to the impact on project success (The Standish Group, 2013). Project success is quantified in terms of time, scope, cost, quality, resources and risk. Project Success may also be viewed from how well the project result assists in organizational governance. Every Project Management Knowledge Area can potentially have an impact on project Success(PMI, 2013). Projects in nature are of different sizes, financial implications, industry, and varying complexities, this has made the search for success factors a long one of about five decades (Davis, 2014; Morteza \& Kamyar, 2009). More importantly, is what passes as a definition of the term success and how project success is perceived by project stakeholders. (Morteza \& Kamyar, 2009) states that some project success factors (PSF) appear to be more significant than others, that they are generic in nature for most types of projects/industries.

(Davis, 2014) said that in early 1970 measures of project success was fixated on the operational side, tools and techniques (Iron triangle of time, cost and quality) and was lacking in any sort of behavioral soft skills (Munns \& Bjeirmi, 1996). It was mainly dependent on the viewpoint of the project manager. Project Managers mainly focused on the technical aspects of the project without proper communication with the clients. During 1980-1990 for the first time, a list of ten success factors including project mission and top management was produced by (Pinto \& Slevin, 1987, 1988) though it was critiqued, thereby bringing to light how imperative it is to evaluate a project from various perspectives. Later (Moris and Hough, 1987) established that success should rely on multiple project stakeholders and the time during which it is measured, though their framework was still based on the iron triangle. During 1990-2000 both internal and external stakeholders were included and specified and Critical Success Factors (CSF) frameworks were created.

In the $21^{\text {st }}$-century project success was defined more than just the Project managers but by the stakeholder expectations.(Papke-shields, Beise, \& Quan, 2010) stated that although the iron triangle often called the traditional criteria of success has been criticized, it is considered by many as the key part of assessing project success. Project Success seems to be developing from the iron triangle of cost time and quality which mainly is the project 
manager's perception to be more focused on the stakeholders such as sponsors (project owner) and project manager combined. Different project stakeholders have different views of how project success should be interpreted, as it is improbable that a single project success criterion will be suitable for all projects, as such frameworks have been developed for measuring project success. Ultimately the aim of project management is to make sure that project success is achieved (Berssaneti \& Carvalho, 2015).

Authors have consistently searched for the best measures of project success often referring to the iron triangle as inadequate, as such attempting to overcome the inadequacies. (Berssaneti \& Carvalho, 2015) classified the attempts into two main approaches;

- Increasing more variables to the traditional criteria (iron triangle), by seeking for more variables that can impact the success

- (Yu et al., 2005) proposed reducing the criteria to a single evaluation criterion, the financial criterion for instance

Regarding the iron triangle (cost, time and quality), (Papke-shields et al., 2010) said that Project Success is achieved when the cost of the project is less or approximately that of the initial budget, time is when the project is on schedule and quality is when the project is executed according to standard. (Lipovetsky, Tishler, Dvir, \& Shenhar, 1997) after studying 110 defense projects opined that the two most important success dimensions are benefits to customer and meeting design goals. They also stated that satisfaction and welfare of customers constituted project success. (Pinto \& Prescott, 1988) highlighted 10 factors: project schedule, client consultation, Technical task, client acceptance, monitoring and feedback, communication, trouble-shooting, management support, personnel (recruitment, selection, and training). (Dvir, Raz, \& Shenhar, 2003) sees Project success as design goals, benefits to customers, commercial success and business potential. (Carù et al., 2004) recognized customer satisfaction as a key to project success. (Morteza \& Kamyar, 2009) held the view of no less than 12 success factors including iron triangle stakeholder satisfaction, scope, project team, project teams, project control, top management support among others.(Chou et al., 2013) considered about 7 factors of which time, budget, quality, design, stakeholder, recurring business and overall business success. There is an overwhelming number of success factors from numerous researchers. Table 3. gives a summary of the project success measures selected for the purpose of this study. With some factors (Publish academic papers, Talent development, Patent Acquisition) being academia-specific which was included as a result of a pilot study aimed at defining project success measures in the academia. In the research study, they are also referred to as Project Success construct.

Table 3. Measures of Project Success

\begin{tabular}{ll}
\hline Project Success constructs & Supportive Literature \\
\hline Completed on time & (Dvir et al., 2003; Papke-shields et al., 2010) \\
Completed within budget & (Dvir et al., 2003; Papke-shields et al., 2010) \\
Meet quality requirement & (Dvir et al., 2003; Papke-shields et al., 2010) \\
Stakeholder satisfaction & (Dvir et al., 2003; Muller \& Turner, 2007; Papke-shields et al., 2010) \\
Project Impact on society & (Joslin \& Müller, 2016) \\
Publish academic papers & (Bostock, 2014) \\
Talent development & \\
Patent Acquisition & \\
\hline
\end{tabular}

\section{Research methodology}

\subsection{Survey process (questionnaire design and development)}

This study utilized the Project Management Body of Knowledge (PMBOK) as the framework for investigating how University researchers actually execute and manage academic researches (projects). It analyzed data obtained from surveys of four universities in the city of Hefei, China. The items to measure the Project management knowledge and Project success was adopted from peer-reviewed publication in the project management research area with a slight modification which is clearly stated in all cases. The survey respondents were University researchers (academics) in the 4 targeted institutions in Hefei City, China.

The questionnaire was initially drafted in the English Language and then translated to the Chinese language by native speakers. To collect the data required, the questionnaire was sent to academics by email. The questionnaire comprised of 4 sections with a total of 35 questions. The questionnaire covered the 10 Project Management Knowledge Areas, questions were presented in an easy to understand manner so as to enable respondents to easily understand the questions and obtain respondents true understanding of the issue. The first section obtained regarding the respondent's background. The section obtained data on the respondents Project Management Knowledge designed along the PMBOK Project Management Knowledge Areas framework. Section three enquired the issue of familiarity, importance, and level of implementation of the Project Management Skills/Techniques/Tools. Finally section four enlisted data on Project Success of accomplished projects. The Likert scale system was employed scoring from 1 to 5, the criteria are adopted from (Morteza \& Kamyar, 2009) and are shown in Table 4. 
Table4. Likert scale scoring criteria (Level of Importance)

\begin{tabular}{ll}
\hline Rating & Score \\
\hline Extreme/Critical & 5 \\
Very important & 4 \\
Moderately Important & 3 \\
Less Important & 2 \\
Not Important (Ignorable) & 1 \\
\hline
\end{tabular}

\subsection{Data collection}

A structured online questionnaire survey was chosen to assess Project management Knowledge of university researchers (academics). The web link for the questionnaire was sent to university academics through email. The snowball approach was used in this survey (Muller \& Turner, 2007) and a total of 119 responses was received over an 8 week period.

Table 5. Socio-economic Characteristics of Survey Respondents

\begin{tabular}{|c|c|c|c|}
\hline \multirow{2}{*}{$\begin{array}{l}\text { Attribute } \\
\text { Gender }\end{array}$} & \multirow{2}{*}{$\begin{array}{l}\text { Distribution } \\
\text { Male }\end{array}$} & \multicolumn{2}{|r|}{ Percentage $(\%)$} \\
\hline & & 99 & 83.19 \\
\hline & Female & 20 & 16.81 \\
\hline & Total & 119 & 100 \\
\hline \multirow[t]{5}{*}{ Age } & $20-30$ & 15 & 12.61 \\
\hline & $31-40$ & 46 & 38.66 \\
\hline & $41-50$ & 41 & 34.45 \\
\hline & $51-60$ & 17 & 14.29 \\
\hline & Total & 119 & 100 \\
\hline \multirow[t]{6}{*}{ Position } & Assistant Lecturer/Research Assistant & 9 & 7.56 \\
\hline & Lecturer/Researcher & 25 & 21.01 \\
\hline & Associate Professor/ Associate Researcher & 50 & 42.02 \\
\hline & Professor/Researcher & 33 & 27.73 \\
\hline & Others & 2 & 1.68 \\
\hline & Total & 119 & 100 \\
\hline \multirow{6}{*}{ Education } & Bachelor's degree & 5 & 4.2 \\
\hline & Master's Degree & 14 & 11.76 \\
\hline & Doctorate Degree & 98 & 82.35 \\
\hline & Others & 1 & 0.84 \\
\hline & Unspecified & 1 & 0.84 \\
\hline & Total & 119 & 100 \\
\hline \multirow[t]{6}{*}{ Faculty } & Engineering Design & 32 & 26.89 \\
\hline & Natural Science & 48 & 40.34 \\
\hline & Social Science & 5 & 4.2 \\
\hline & Management & 31 & 26.05 \\
\hline & Others & 3 & 2.52 \\
\hline & Total & 119 & 100 \\
\hline \multirow[t]{6}{*}{ Work experience(years) } & $<5$ & 17 & 14.29 \\
\hline & $6-10$ & 32 & 26.89 \\
\hline & $11-15$ & 26 & 21.85 \\
\hline & $16-20$ & 21 & 17.65 \\
\hline & $>20$ & 23 & 19.33 \\
\hline & Total & 119 & 100 \\
\hline \multirow[t]{11}{*}{ Project Scale(RMB) } & $<50000$ & 12 & 10.08 \\
\hline & $50,001-100,000$ & 13 & 10.92 \\
\hline & $100,001-500,000$ & 50 & 42.02 \\
\hline & $500,001-1,000,000$ & 23 & 19.33 \\
\hline & $1,000,001-2,000,000$ & 9 & 7.56 \\
\hline & $2,000,001-5,000,000$ & 7 & 5.88 \\
\hline & $5,000,001-10,000,000$ & 2 & 1.68 \\
\hline & $10,000,001-20,000,000$ & 1 & 0.84 \\
\hline & $>20,000,000$ & 1 & 0.84 \\
\hline & Unspecified & 1 & 0.84 \\
\hline & Total & 119 & 100 \\
\hline
\end{tabular}

Note: RMB= Ren Min Bi (currency of China)

Table 5 gives the demographic characteristics of the respondents. The percentage of male respondents was $83.19 \%$ while that of female respondents was $16.81 \%$, most respondents fell into the $31-40$ years age group 
amounting to $38 \%$. Most respondents had a Doctorate degree $(82.35 \%)$ and $42.02 \%$ of respondents were Associate professor/Associate Researcher. Almost half (48\%) have a degree in the field of Natural sciences followed closely by the field of Management (31\%). 26.89\% of the respondents have 6-10 years of work experience. $42.02 \%$ of respondents have handled a project scale of $100,000 \mathrm{rmb}$ or more.

\subsection{Data analysis methods}

The various methods of analyzing data are listed below with justification for the choices made:

3.3.1 Validity and reliability $(\alpha)$

Content and construct validity were achieved by using literature-based measurement dimensions and face validity was tested and ensured during the pilot study. Reliability is concerned with the ability of an instrument to measure consistency. It is the most widely used measure of reliability developed by Lea Cronbach in 1951. Reliability was measured using Cronbach's alpha given that Cronbach's alpha coefficient is considered the standard tool for assessing internal consistency and reliability, the reliability of each construct was also investigated using the Cronbach's alpha. For constructs to exhibit reliability they should have a minimum value of 0.70 (Hair, Black, Babin, \& Anderson, 2010).

Cronbach's alpha $(\alpha)$ is represented mathematically as;

$\alpha=\frac{k}{k-1}\left(1-\frac{\sum_{i=1}^{k} s_{i}^{2}}{s^{2}}\right)$

Where;

$\alpha=$ Cronbach's alpha coefficient

$\mathrm{k}=$ number of the measured indicators of the latent construct

$s_{i}^{2}=$ variance of each indicator;

$s^{2}=$ The total variance of the measured indicators

3.3.2 Inferential statistics

Correlation

For the 117 responses, the sampling distribution should take the shape of a normal distribution (Field, 2009) as such Pearson's Correlation Coefficient test was chosen to analyze the data. The relationship between dependent variables (Project success) and independent variables (PMKA constructs) was investigated using Bi-variate correlation analysis. Correlations values could be low $(<0.3)$, moderate $(0.3-0.7)$ or high $(>0.7)$.

Regression analysis

Linear regression was carried out to further validate the correlations with respect to the individual research hypotheses to understand the level of significance and how much variance the PMKA have on Project Success. Multiple regression was subsequently carried out to generate the best fit model so as to explain the variance in the dependent variable (Project Success).

Durbin-Watson test and variance inflation factor (vif)

This test was carried out to check the issue of autocorrelations in the residuals, while the VIF test was performed for the independent variables with the Project Success construct where values of less than 5 are considered acceptable (Hair et al., 2010).

3.3.3 Importance-performance analysis (IPA)

Developed by Martilla and James in 1977 is a two-dimensional graph way to assess the quality of service. It includes a graphical representation showing the importance and performance ratings of the attributes(Ford \& Joseph, 1999; Jesus \& Silva, 2010; Martilla, J. A., and James, 1977). They also stated that it is an alternative way of assessing service quality based on the importance or performance paradigm. Data collected is used to construct a two-dimensional matrix, which is divided into four quadrants based on the means of importance and performance as shown in Fig 2. 


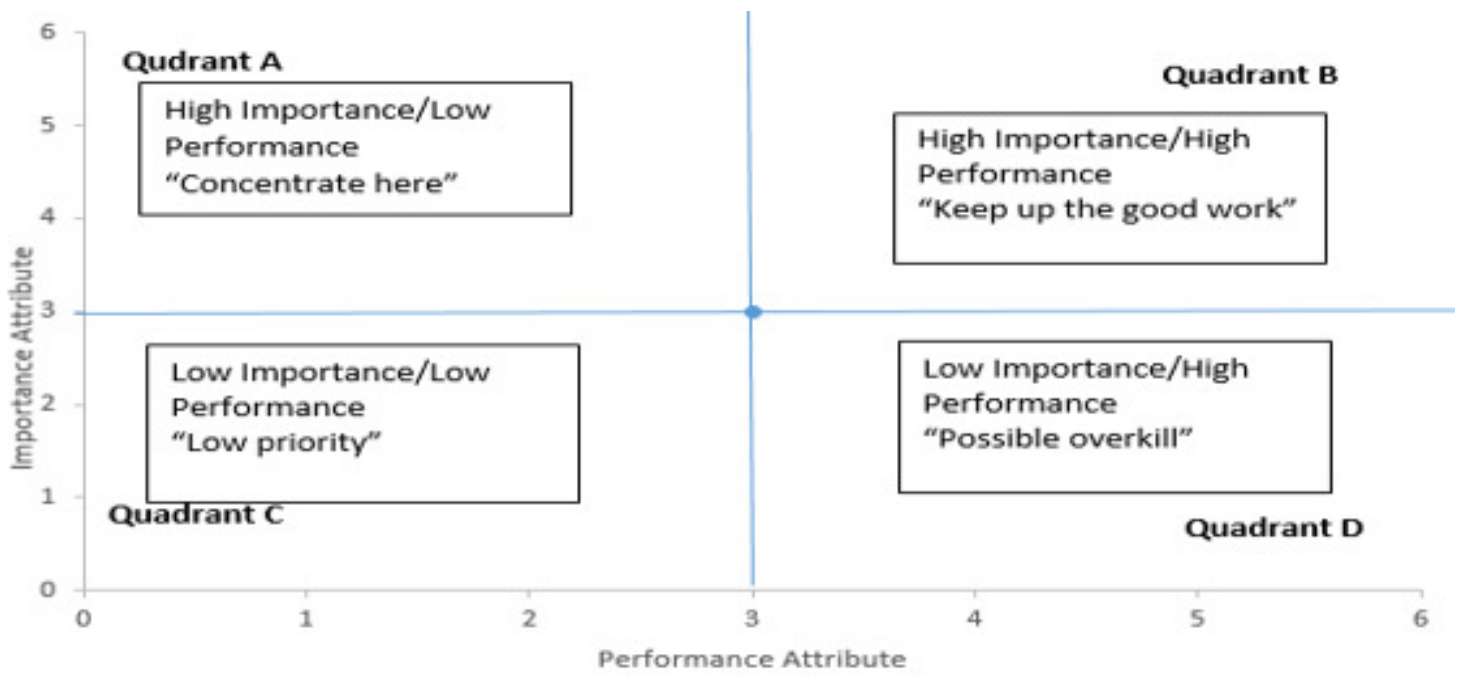

Fig. 2. Importance-performance matrix

For the Quadrant A, high importance and low performance, the project manager should concentrate here and must strive to improve the indicators because these indicators should have priority for corrective action or need more attention. The Quadrant B refers to high importance and high performance, indicators in this quadrant are sources of competitive advantage and the Project manager should keep up the good work with the indicators here i.e. efforts should be maintained. Quadrant $\mathrm{C}$ refers to the low priority quadrant, where there is low importance and low performance, here Project managers should not worry even if performance is low because it is not of much importance for the time being, opportunities may come up later to make it better. Quadrant D refers to low importance and high performance where the Project manager is making excessive efforts.

\section{Data analysis and results}

\subsection{Validity and reliability}

Content and construct validity were achieved by using literature-based measurement dimensions and face validity was tested and ensured during the pilot study. Using Cronbach's alpha, reliability for each construct was investigated. Reliability was assumed for all constructs which demonstrated Cronbach's alpha value of greater than 0.70 (Hair et al., 2010). All questionnaire items loaded on their respective constructs of PMKA and the Project Success construct.

4.1.1 Project management knowledge area (pmka)

The Final result for PMKA which comprised 10 constructs was 95.3\%. The highest being recorded in PRM (94.4\%) and the lowest value recorded in PIM (79.5\%).

4.1.2 Project success

The Project Success variable comprised of 8 constructs. Project Success had high reliability of 92.4\%.

Since all the items loaded acceptable reliability, the results confirmed the appropriateness of further data analysis.

Table 6a. Pearson's correlation of independent and dependent variables

\begin{tabular}{|c|c|c|c|c|c|c|c|c|c|c|c|c|}
\hline & PIM & PSM & РТМ & РСМ & PQM & PHRM & РСОМ & PRM & PPM & PSHM & PMKA & $\begin{array}{l}\text { Project } \\
\text { Success }\end{array}$ \\
\hline PIM & 1 & & & & & & & & & & & \\
\hline PSM & $.633^{* *}$ & 1 & & & & & & & & & & \\
\hline PTM & $.662^{* *}$ & $.752^{* *}$ & 1 & & & & & & & & & \\
\hline PCM & $.691^{* *}$ & $.629^{* *}$ & $.668^{* *}$ & 1 & & & & & & & & \\
\hline PQM & $.589^{* *}$ & $.772^{* *}$ & $.724^{* *}$ & $.690^{* *}$ & 1 & & & & & & & \\
\hline PHRM & $.601^{* *}$ & $.719^{* *}$ & $.737^{* *}$ & $.730^{* *}$ & $.800^{* *}$ & 1 & & & & & & \\
\hline PCOM & $.676^{* *}$ & $.709^{* *}$ & $.761^{* *}$ & $.721^{* *}$ & $.754^{* *}$ & $.825^{* *}$ & 1 & & & & & \\
\hline PRM & $.629^{* *}$ & $.561^{* *}$ & $.546^{* *}$ & $.721^{* *}$ & $.570^{* *}$ & $.640^{* *}$ & $.700^{* *}$ & 1 & & & & \\
\hline PPM & $.609^{* *}$ & $.554^{* *}$ & $.533^{* *}$ & $.767^{* *}$ & $.555^{* *}$ & $.602^{* *}$ & $.706^{* *}$ & $.707^{* *}$ & 1 & & & \\
\hline PSHM & $.550^{* *}$ & $.579^{* *}$ & $.609^{* *}$ & $.612^{* *}$ & $.563^{* *}$ & $.600^{* *}$ & $.693^{* *}$ & $.722^{* *}$ & $.711^{* *}$ & 1 & & \\
\hline PMKA & $.797^{* *}$ & $.839^{* *}$ & $.846^{* *}$ & $.955^{* *}$ & $.838^{* *}$ & $.863^{* *}$ & $.904^{* *}$ & $.812^{* *}$ & $.798^{* *}$ & $.805^{* *}$ & 1 & \\
\hline $\begin{array}{l}\text { Project } \\
\text { Success }\end{array}$ & $.646^{* * \mathrm{~b}}$ & $.537^{* * *_{\mathrm{c}}}$ & $.579^{* * \mathrm{~d}}$ & $.728^{* *} \mathrm{e}$ & $.623^{* * \mathrm{f}}$ & $.643^{* * g}$ & $.666^{* * \mathrm{~h}}$ & $.675^{* *_{\mathrm{i}}}$ & $.679^{* * *_{j}}$ & $.622^{* * \mathrm{k}}$ & $.757^{* * a}$ & 1 \\
\hline
\end{tabular}

**. Correlation is significant at the 0.01 level (2-tailed).

$\mathrm{Bi}$-variate association specific to study hypotheses

${ }^{\mathrm{a}} \mathrm{H} 1,{ }^{\mathrm{b}} \mathrm{H} 2,{ }^{\mathrm{c}} \mathrm{H} 3,{ }^{\mathrm{d}} \mathrm{H} 4,{ }^{\mathrm{e}} \mathrm{H} 5,{ }^{\mathrm{f}} \mathrm{H} 6,{ }^{\mathrm{g}} \mathrm{H} 7,{ }^{\mathrm{h}} \mathrm{H} 8,{ }^{\mathrm{i}} \mathrm{H} 9,{ }^{\mathrm{j}} \mathrm{H} 10,{ }^{\mathrm{k}} \mathrm{H} 11$ 
Table 6b. Pearson's correlation of individual PMKA variables and Project Success variables

\begin{tabular}{lllllllllll}
\hline & PIM & PSM & PTM & PCM & PQM & PHRM & PCOM & PRM & PPM & PSHM \\
\hline Completed on time & $.529^{* *}$ & $.508^{* *}$ & $.510^{* *}$ & $.623^{* *}$ & $.563^{* *}$ & $.581^{* *}$ & $.599^{* *}$ & $.529^{* *}$ & $.575^{* *}$ & $.507^{* *}$ \\
Completed within budget & $.552^{* *}$ & $.481^{* *}$ & $.552^{* *}$ & $.606^{* *}$ & $.548^{* *}$ & $.573^{* *}$ & $.588^{* *}$ & $.640^{* *}$ & $.607^{* *}$ & $.543^{* *}$ \\
Meet quality requirement & $.563^{* *}$ & $.460^{* *}$ & $.514^{* *}$ & $.647^{* *}$ & $.471^{* *}$ & $.545^{* *}$ & $.613^{* *}$ & $.603^{* *}$ & $.559^{* *}$ & $.532^{* *}$ \\
Stakeholder satisfaction & $.525^{* *}$ & $.396^{* *}$ & $.420^{* *}$ & $.527^{* *}$ & $.467^{* *}$ & $.522^{* *}$ & $.514^{* *}$ & $.570^{* *}$ & $.559^{* *}$ & $.497^{* *}$ \\
Project Impact on society & $.462^{* *}$ & $.319^{* *}$ & $.392^{* *}$ & $.441^{* *}$ & $.353^{* *}$ & $.382^{* *}$ & $.389^{* *}$ & $.400^{* *}$ & $.431^{* *}$ & $.384^{* *}$ \\
Publish academic papers & $.517^{* *}$ & $.426^{* *}$ & $.438^{* *}$ & $.550^{* *}$ & $.529^{* *}$ & $.490^{* *}$ & $.522^{* *}$ & $.598^{* *}$ & $.535^{* *}$ & $.467^{* *}$ \\
Talent development & $.432^{* *}$ & $.388^{* *}$ & $.408^{* *}$ & $.486^{* *}$ & $.442^{* *}$ & $.403^{* *}$ & $.441^{* *}$ & $.451^{* *}$ & $.559^{* *}$ & $.472^{* *}$ \\
Patent acquisition & $.500^{* *}$ & $.378^{* *}$ & $.446^{* *}$ & $.581^{* *}$ & $.512^{* *}$ & $.540^{* *}$ & $.521^{* *}$ & $.545^{* *}$ & $.546^{* *}$ & $.545^{* *}$ \\
\hline
\end{tabular}

\subsection{Inferential statistics}

\subsubsection{Pearson's correlation coefficient test}

This parametric test result showed that Project success construct was significantly correlated with PMKA variables and constructs. Table 6 . shows the correlation matrix of the variables. The following observations were made from the correlation matrix;

i. All hypotheses were supported through the statistically significant relationship $(\mathrm{p}<0.01)$ between the independent variables (PMKA) and the dependent variable (Project Success).

ii. Table 6a. Demonstrated medium to a high correlation between constructs. The most correlated variables with the Project Success variables are PCM (0.728), PPM (0.696) and PCOM (0.687) while the lowest correlation associated with Project Success construct is PSM (0-571). As evidenced by the values in Table 6a. no low correlations are recorded for the PMKA constructs and Project Success and all values were statistically significant at $\mathrm{p}<0.01$.

iii. Table 6b. Also shows that PMKA constructs and individual Project Success constructs similarly shows moderate values of correlation with the highest value observed between PCM and Meet quality requirement (0.647) while the lowest value is observed between PSM and Impact on Society (0.319).

4.2.2 Linear regression of PMKA constructs and Project Success.

Linear regression results are presented in Table 7 . The following observations were made;

i. PMKA explained $62 \%$ of the variance in Project Success while a very significant relationship was explained by $F$ values and Beta values $(F=190.356, \beta=0.790, p<0.001)$.

ii. The variances were explained by PCM (52.6\%), PPM (48\%), PCOM (46.7\%) in Project Success with F values of $129.888,108.009,102.510$ and beta values of $0.728,0.696,0.687(\mathrm{p}<0.001)$ respectively. The least variance of $32.1 \%$ was recorded by PSM $(\mathrm{F}=55.772, \beta=0.571)$.

iii. All other relations were significant with most individually explaining more than $40 \%$ in Project Success. 4.2.3 Variance Inflation Factor (VIF) and Durbin Watson

(Field, 2009) stated that VIF values of less than 10 and tolerance level greater than 0.2 confirm the lack of collinearity in the data set as such multiple regression modeling can be carried out. The VIF results for the PMKA constructs with Project Success fulfills this requirement. (Field, 2009) further stated that Durbin Watson values of about 2 are considered acceptable, the statistics in Table 7. fulfilled this condition i.e. autocorrelation was absent in the residuals.

Table 7. Summarized results of hypothesis testing using linear regression

\begin{tabular}{|c|c|c|c|c|c|c|c|c|c|c|c|c|c|c|c|}
\hline Ref & $\begin{array}{c}\text { Independent } \\
\text { Variables }\end{array}$ & $\begin{array}{c}\text { Dependent } \\
\text { Variable }\end{array}$ & $\mathbf{R}$ & $\begin{array}{c}\mathbf{R} \\
\text { Square }\end{array}$ & $\begin{array}{l}\text { Adjusted } \\
\text { R Square }\end{array}$ & $\begin{array}{l}\text { Durbin- } \\
\text { Watson }\end{array}$ & $\mathbf{F}$ & Sig. & $\mathbf{t}$ & Sig. & $\begin{array}{l}\begin{array}{l}\text { Unstan } \\
\text { coef }\end{array} \\
\text { cof }^{2}\end{array}$ & $\begin{array}{l}\text { ardized } \\
\text { cient } \\
\text { SE }\end{array}$ & $\begin{array}{c}\text { Standard } \\
\text { coefficient (Beta) }\end{array}$ & Tolerance & VIF \\
\hline \multirow[t]{2}{*}{ HI } & Constant & Project Success & $.790^{\mathrm{a}}$ & 0.623 & 0.62 & & 190.358 & $.000^{\mathrm{b}}$ & 3.461 & 0.001 & 0.69 & 0.199 & & & \\
\hline & PMKA & & & & & 2.096 & & & 13.797 & 0.000 & 0.733 & 0.053 & 0.79 & & \\
\hline \multirow[t]{2}{*}{ H2 } & Constant & Project Success & $.676^{a}$ & 0.458 & 0.453 & & 96.995 & $.000^{\mathrm{b}}$ & 6.086 & 0.000 & 1.313 & 0.216 & & & \\
\hline & PIM & & & & & 1.764 & & & 9.849 & 0.000 & 0.576 & 0.059 & 0.676 & 0.402 & 2.491 \\
\hline \multirow[t]{2}{*}{ H3 } & Constant & Project Success & $.571^{\mathrm{a}}$ & 0.327 & 0.321 & & 55.772 & $.000^{\mathrm{b}}$ & 6.439 & 0.000 & 1.588 & 0.247 & & & \\
\hline & PSM & & & & & 2.022 & & & 7.468 & 0.000 & 0.451 & 0.06 & 0.571 & 0.305 & 3.284 \\
\hline \multirow[t]{2}{*}{ H4 } & Constant & Project Success & $.605^{\mathrm{a}}$ & 0.366 & 0.361 & & 66.476 & $.000^{\mathrm{b}}$ & 5.719 & 0.000 & 1.414 & 0.247 & & & \\
\hline & PTM & & & & & 1.995 & & & 8.153 & 0.000 & 0.502 & 0.062 & 0.605 & 0.277 & 3.609 \\
\hline \multirow[t]{2}{*}{ H5 } & Constant & Project Success & $.72 \mathrm{~s}^{\mathrm{a}}$ & 0.53 & 0.526 & & 129.888 & $.000^{\mathrm{b}}$ & 7.383 & 0.000 & 1.356 & 0.184 & & & \\
\hline & PCM & & & & & 2.112 & & & 11.397 & 0.000 & 0.573 & 0.05 & 0.728 & 0.237 & 4.214 \\
\hline \multirow[t]{2}{*}{ H6 } & Constant & Project Success & $.676^{\mathrm{a}}$ & 0.457 & 0.453 & & 96.883 & $.000^{\mathrm{b}}$ & 6.065 & 0.000 & 1.311 & 0.216 & & & \\
\hline & PQM & & & & & 1.874 & & & 9.843 & 0.000 & 0.526 & 0.053 & 0.676 & 0.261 & 3.83 \\
\hline \multirow[t]{2}{*}{ H7 } & Constant & Project Success & $.679^{\mathrm{a}}$ & 0.461 & 0.456 & & 98.406 & $.000^{\mathrm{b}}$ & 6.063 & 0.000 & 1.305 & 0.215 & & & \\
\hline & PHRM & & & & & 2.025 & & & 9.92 & 0.000 & 0.552 & 0.056 & 0.679 & 0.223 & 4.492 \\
\hline \multirow[t]{2}{*}{ H8 } & Constant & Project Success & $.687 \mathrm{a}$ & 0.471 & 0.467 & & 102.51 & $.000^{\mathrm{b}}$ & 6.54 & 0.000 & 1.351 & 0.206 & & & \\
\hline & PCOM & & & & & 1.915 & & & 10.125 & 0.000 & 0.555 & 0.055 & 0.687 & 0.197 & 5.086 \\
\hline \multirow[t]{2}{*}{ H9 } & Constant & Project Success & $.685^{\mathrm{a}}$ & 0.47 & 0.465 & & 101.837 & $.000^{\mathrm{b}}$ & 10.805 & 0.000 & 1.787 & 0.165 & & & \\
\hline & PRM & & & & & 2.123 & & & 10.091 & 0.000 & 0.473 & 0.047 & 0.685 & 0.319 & 3.138 \\
\hline \multirow[t]{2}{*}{ H10 } & Constant & Project Success & $.696^{a}$ & 0.484 & 0.48 & & 108.009 & $.000^{\mathrm{b}}$ & 10.535 & 0.000 & 1.74 & 0.165 & & & \\
\hline & PPM & & & & & 1.972 & & & 10.393 & 0.000 & 0.504 & 0.049 & 0.696 & 0.281 & 3.553 \\
\hline \multirow[t]{2}{*}{ HII } & Constant & Project Success & $.645^{\mathrm{a}}$ & 0.416 & 0.411 & & 82.051 & $.000^{\mathrm{b}}$ & 10.864 & 0.000 & 1.882 & 0.173 & & & \\
\hline & PSHM & & & & & 1.96 & & & 9.058 & 0.000 & 0.433 & 0.048 & 0.645 & 0.344 & 2.908 \\
\hline
\end{tabular}




\subsection{Multiple Regression}

The step-wise method of regression was selected to generate the model of best fit, explaining most variance in the dependent variable (Project Success) the results are given in Tables 8a and 8b. The best fit model was Model 4. With PIM, PCM, PQM, and PSHM collectively defining $64.1 \%$ of the variance in Project Success.

Table 8a. Multiple regression test

\begin{tabular}{llllll}
\hline Model & R & R Square & Adjusted R Square & F & Sig. \\
\hline 1 & $.728^{\mathrm{a}}$ & 0.530 & 0.526 & 129.888 & $.000^{\mathrm{b}}$ \\
2 & $.771^{\mathrm{b}}$ & 0.594 & 0.587 & 83.444 & $.000^{\mathrm{c}}$ \\
3 & $.793^{\mathrm{c}}$ & 0.629 & 0.620 & 63.992 & $.000^{\mathrm{d}}$ \\
4 & $.808^{\mathrm{d}}$ & 0.653 & 0.641 & 52.734 & $.000^{\mathrm{e}}$ \\
\hline
\end{tabular}

a. Predictors: (Constant), PCM

b. Predictors: (Constant), PCM, PSHM

c. Predictors: (Constant), PCM, PSHM, PIM

d. Predictors: (Constant), PCM, PSHM, PIM, PQM

e. Dependent Variable: Project Success

Table 8b. Multiple regression coefficients

\begin{tabular}{|c|c|c|c|c|c|}
\hline \multirow[b]{2}{*}{ Model } & \multicolumn{2}{|c|}{ Unstandardized Coefficients } & \multicolumn{3}{|c|}{ Standardized Coefficients } \\
\hline & B & Std. Error & Beta & $\mathrm{t}$ & Sig. \\
\hline $4 \quad$ (Constant) & 0.701 & 0.196 & & 3.580 & 0.001 \\
\hline PCM & 0.220 & 0.072 & 0.280 & 3.075 & 0.003 \\
\hline PSHM & 0.149 & 0.050 & 0.223 & 3.017 & 0.003 \\
\hline PIM & 0.195 & 0.068 & 0.229 & 2.859 & 0.005 \\
\hline PQM & 0.173 & 0.063 & 0.223 & 2.767 & 0.007 \\
\hline
\end{tabular}

\subsection{Importance-Performance Analysis}

IPA values were estimated using a method adapted from (Chou et al., 2013)using importance values from the output and performance rating from the overall questionnaire data. The mean importance weight was 0.537 and mean performance was 3.64. The results are presented in Figure 3. The indicators considered as most important and corresponding mean values were of the PPM construct (0.586), PRM (0.574), PCOM (0.564), PCM (0.553) and PQM (0.547). While the high performances and corresponding mean values perceived by respondents were PSM (3.988), PQM (3.943), PTM (3.917), and PPM (3.26). The importance-performance matrix is represented in Figure 3. and the 4 different quadrants are defined by overall median values $(3.64,0.537)$ as suggested and implemented by (Jesus and Silva, 2010; Lynch et al., 2008; Martilla and James, 1977) and stating that median values are preferable to mean as measures of central tendency. The results are spread over all four quadrant: in the Quadrant B, Keep up the good work quadrant indicators included PCOM, PQM, these are perceived to be of paramount importance with good performance (and often used) indicating that University researchers should continue to consider and utilize these indicators so as to strive to maximize Project success. Focusing on them can increase project success as it is a point of comparative advantage. For the quadrant A, concentrate here quadrant, indicators such as PPM, PRM, and PCM need more attention in other to maximize project success, more effort should be placed on these indicators. For the low priority quadrant only PIM, PSHM is featured there and is not of much importance to Project Success. While for possible overkill (quadrant D) PTM, PSM, and PHRM mean that not much effort should be placed here as it has little effect on Project Success. For now, less attention should be accorded to them but such status may change in the future. 


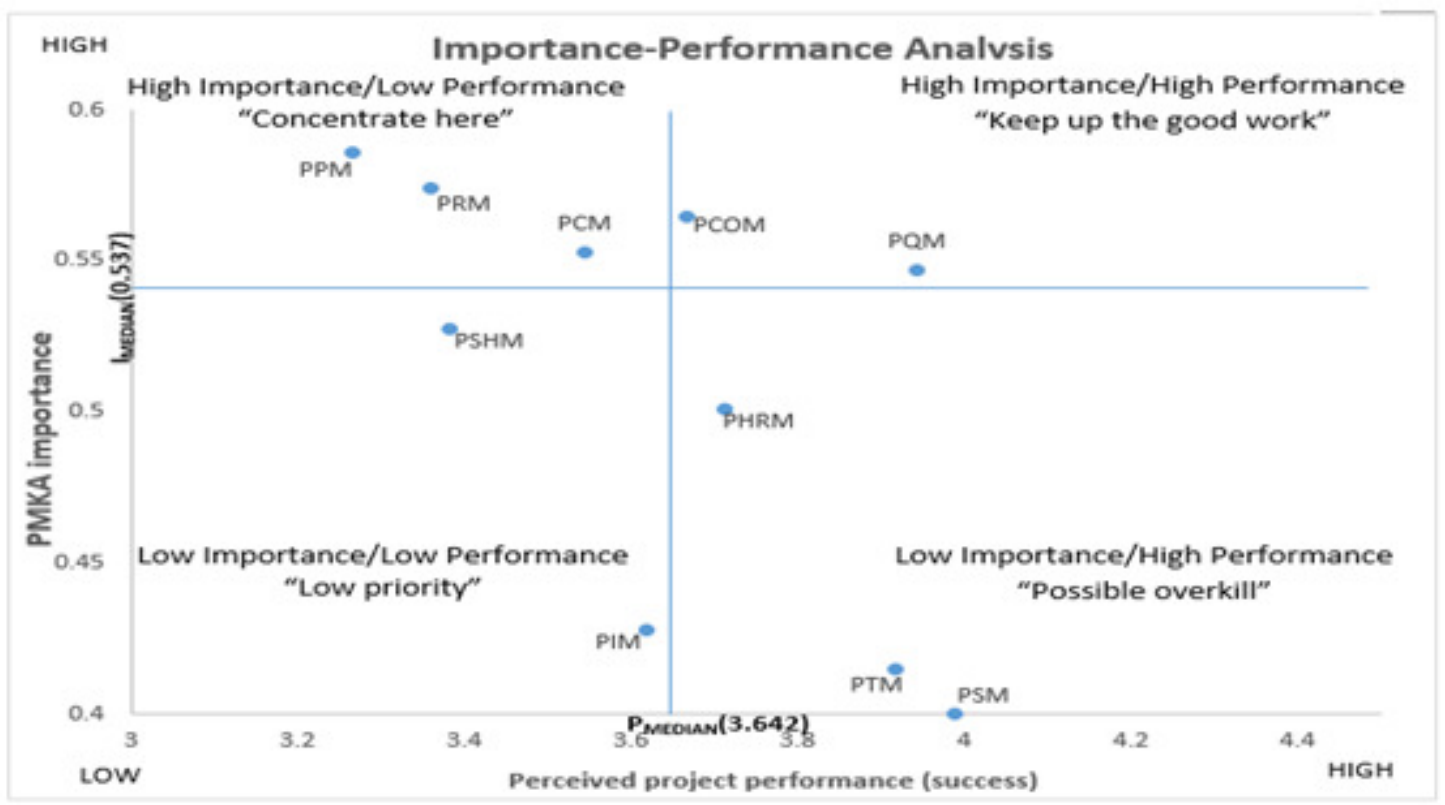

Fig. 3. Importance-Performance result

\section{Discussion}

\subsection{PMKA to Project Success Relationship}

The statistically positive relationship found between PMKA and Project Success is consistent with PMBOK guide (PMI, 2013) and that individual PMKA has the potential to contribute to Project Success. The linear regression shows that PMKA explained $62 \%$ of the variance in Project Success with a significant relationship explain by F value and $\beta$ values $(\mathrm{F}=190.385 \beta=0.790, \mathrm{p}<0.001)$ thereby showing that by properly understanding the PMKA, Project Success can be significantly increased. This lends support to confirm hypothesis H1. Though $38 \%$ still remains unexplained, it would depend on factors other than PMKA. The unexplained variance is not within the scope of this study but should be explored further.

\subsection{Influence of Individual PMKA constructs on Project Success.}

All other hypotheses $\mathrm{H} 2-\mathrm{H} 11$ predicting a statistical relationship between the independent variable PMKA construct and the dependent variable(Project Success). Their findings clearly show that enhanced Project Success can be achieved by focusing on the individual constructs of PMKA.

Pearson's Correlation and Linear regression results found that;

- $\mathrm{PCM}$ is the most significant individual variable that contributed to project success. This suggests properly understanding and implementing PCM can significantly impact Project Success. The significance of PCM comes as no surprise because it is evident in the iron triangle of Cost, Time and Quality. Cost being among the critical success factors makes it essential for both short and long term benefits of projects. University researchers and Universities alike should work on better ways of planning, estimating, budgeting, financing, funding, managing and controlling cost.

- PPM is the next most important variable that contributed to Project Success. This is also expected as research has shown that academics mainly consider project funding or procurement of certain equipment for their projects as it is an external requirement which cannot be met by the project team as such it must be sourced externally. PCM and PPM are closely related, this is because the acquisition of products and services can be effectively done through PCM input.

- PSM and PTM recorded the lowest variances of $32.1 \%$ and $36.1 \%$ and the lowest correlations to Project Success though significant $(0.571$ and 0.605$)$ respectively, which means University researcher consider them least. This is evidenced by the constant review of the scope of their research as depending on the developments in their field, while in the case of PTM it follows to reason that qualitative research sometimes requires long periods of time to carry out research.

Considering the multiple regression model of best fit the combined effects of PIM, PCM, PQM, and PSHM explain most of the variance in Project Success. These four variables account $64.1 \%$ variance in Project Success while other factors account for $35.9 \%$ variance. The redundancy of PSM, PTM, PHRM, PCOM, PRM, and PPM is seen. 


\section{Conclusion/contribution/recommendation}

6.1 Conclusion

This research study utilized the Regression analysis method to demonstrate the relationship between PMBOK Knowledge areas and Project Success of University researchers. By gaining insight knowledge into Project Management Knowledge of University researchers and understanding this relationship, researchers, as well as Universities, can further increase Project Success personally and institutionally. The IPA technique was employed or applied to understand which indicators attributes are properly utilized and which indicators should be improved so as to improve the overall Project Success. By Carrying out a quantitative analysis of the effect of Project Management Knowledge areas on Project Success and subsequently the Importance-Performance Analysis, Academics can effectively manage resources at their disposal to improve Project Success of researches.

The analytical results in this study confirm that, although academicians in China often use certain elements of PMBOK framework in their research projects, they are not adequately familiar with the exact content of PMBOK and as such do not fully utilize the PMBOK framework in the daily management of research projects. The findings of this study provide guidance for academics and Institutions (Universities) by clarifying the current use of PMBOK knowledge Areas and the extent to which it contributes to research project success in the academic field. Project managers who wish to optimize project success can utilize the model to perform numerical studies of critical indicators/constructs and to prioritize and allocate the components to their managerial strategies.

Findings have shown that there is a significant relationship between all the knowledge areas and project success. All the 11 hypotheses were supported. Through Linear Regression analysis, PMKA explains 62\% variance in Project Success. PCM and PPM were most influential to Project Success explaining that University researchers attach more importance to what they cannot get from the project team as such must be sourced externally. PSM and PTM were the least significant Knowledge areas. Through the Importance-Performance Analysis (IPA) we concluded that that the attributes considered most important by the respondents were; PPM, PRM, PCOM, PCM, and PQM while PSM was considered least important. It is important to note that the IPA which was key in identifying the importance and performance of the indicators in the quadrants aids in developing management strategies for improving project success.

Based on the findings of this research the following bits of advice are given to University researchers and university management:

University researchers should endeavor to pay attention to PIM, PCM, PQM, and PSHM as these knowledge areas have been found to have the most impact on project success in this study, the effective management of these areas could significantly impact project success. This can be done by acquiring the requisite knowledge for these areas, through training or programs designed for this purpose. Implementing PCM deals with estimating and controlling costs within the budget, implementing PQM would ensure that quality requirements are achieved, implementing PSHM would ensure that all stakeholders of the project are identified and engaged in project decisions and execution while implementing PIM whole ensure that university researchers understand how different knowledge areas interact towards the successful completion of projects.

University management should aim to improve the understanding of the researcher's project management knowledge in these areas (PIM, PCM, PQM, and PSHM) due to its impact on project success. They should also endeavor to put in place systems that will ease the university researcher's acquisition and implementation of skills related to these knowledge areas.

\subsection{Contribution}

The research study makes a contribution to the body of knowledge this is because the literature on this area of research especially in the area of academia is largely scanty. This research also provides empirical evidence of the relationship between PMBOK knowledge area and project success in academia. Further explaining which factors enhance project success. It also contributes to practical knowledge in academia.

\subsection{Recommendations}

Universities should invest in project management programs targeted at university researchers be it generally or at faculty level, this is because many researchers are subject matter experts and such project management training programs may help in managing research projects more effectively. Empowering university researchers with such knowledge will have significant input in the success of their research projects. Indicators in this study were developed by applying PMBOK knowledge areas. Future studies can evaluate other indicators of project management knowledge areas and project success. Sample size can be expanded, the number of indicators can also be increased. Other studies can examine other industries.

\section{References}

APM. (2016). The State of Project Management - CIO Annual Survey 2016. Retrieved from http://www.cio.com.au/article/143117/state_project_management/?fp=4\&fpid=21 
Berssaneti, F. T., \& Carvalho, M. M. (2015). Identification of variables that impact project success in Brazilian companies. International Journal of Project Management, 33(3), 638-649. https://doi.org/10.1016/j.ijproman.2014.07.002

Bostock, J. (2014). The Meaning of Success Insights from Women at Cambridge. Cambridge: Cambridge University Press.

Carù, A., Cova, B., \& Pace, S. (2004). Project success: Lessons from the Andria case. European Management Journal, 22(5), 532-545. https://doi.org/10.1016/j.emj.2004.09.011

Chou, J., Irawan, N., \& Pham, A. (2013). Project Management Knowledge of Construction Professionals: CrossCountry Study of Effects on Project Success, 1-15. https://doi.org/10.1061/(ASCE)CO.1943-7862.0000766.

Davis, K. (2014). Different stakeholder groups and their perceptions of project success. International Journal of Project Management, 32(2), 189-201. https://doi.org/10.1016/j.ijproman.2013.02.006

Dvir, D., Raz, T., \& Shenhar, A. J. (2003). An empirical analysis of the relationship between project planning and project success, 21, 89-95.

Field, A. (2009). Discovering Statistics Using SPSS, Third Edition. London: SAGE Publications.

Ford, J. B., \& Joseph, B. (1999). Importance-performance analysis as a strategic tool for service marketers : the case of service quality perceptions of business students in New Zealand and the USA, 13(2), 171-186.

Gale, S. F. (2009). Closing the gap: The link between project management excellence and long-term success. Economist Intelligence Unit, 1-27. Retrieved from https://docs.google.com/viewer?a=v\&q=cache:DZUSMHCr4zoJ:viewswire.eiu.com/report_dl.asp?mode=fi $\& \mathrm{fi}=1865031771$. PDF $\& \mathrm{rf}=0+$ Project + Management + competency+amongst $+\mathrm{IS}+$ Professionals $\&$ hl=en $\&$ pid $=$ bl\&srcid=ADGEESicKyYAtWsqQVDxpmXWT1AORyKW sHfeH1FRj66jTmBLmTdysOu WDCrN

Hair, J., Black, W., Babin, B., \& Anderson, R. (2010). Multivariate Data Analysis a Global Perspective, Prentice Hall. Upper Saddle River, NJ.

Jesus, F. De, \& Silva, H. (2010). Importance-Performance Analysis As A Tool In Evaluating Higher Education Service Quality: The Empirical Results Of Estig ( IPB ) 2010, 306-315.

Joslin, R., \& Müller, R. (2016). The relationship between project governance and project success. International Journal of Project Management, 34(4), 613-626. https://doi.org/10.1016/j.ijproman.2016.01.008

Ling, F., \& Low, S. (2008). Models for predicting project performance in China using project management practices adopted by foreign AEC firms. Journal of Construction ..., (December 2008), 983-990. Retrieved from http://ascelibrary.org/doi/abs/10.1061/(ASCE)0733-9364(2008)134:12(983)

Lipovetsky, S., Tishler, A., Dvir, D., \& Shenhar, A. (1997). The relative importance of project success dimensions. $R$ and D Management. https://doi.org/10.1111/1467-9310.00047

Lynch, J., Carver, R., \& Virgo, J. M. (2008). Quadrant Analysis as a Strategic Planning Technique in Curriculum Development and Program Marketing, 1241. https://doi.org/10.1300/J050v07n02

Martilla, J. A., and James, J. C. (1977). Importance-performance analysis. J.Market, 41(1), 77-79.

Mir, F. A., \& Pinnington, A. H. (2014). Exploring the value of project management: Linking Project Management Performance and Project Success. International Journal of Project Management, 32(2), $202-217$. https://doi.org/10.1016/j.ijproman.2013.05.012

Morteza, S.-G., \& Kamyar, K.-C. (2009). Generic project success and project management success criteria and factors: Literature review and survey. WSEAS Transactions on Business and Economics, 6(8), 456-468.

Muller, R., \& Turner, R. (2007). The Influence of Project Managers on Project Success Criteria and Project Success by Type of Project, 25(4), 298-309. https://doi.org/10.1016/j.emj.2007.06.003

Munns, A. K., \& Bjeirmi, B. F. (1996). The role of project management in achieving project success. International Journal of Project Management, 14(2), 81-87. https://doi.org/http://dx.doi.org/10.1016/02637863(95)00057-7

Pant, I., \& Baroudi, B. (2008). Project management education: The human skills imperative, 26, $124-128$. https://doi.org/10.1016/j.ijproman.2007.05.010

Papke-shields, K. E., Beise, C., \& Quan, J. (2010). Do project managers practice what they preach , and does it matter to project success? International Journal of Project Management, 28(7), 650-662. https://doi.org/10.1016/j.ijproman.2009.11.002

Pinto, J. K., \& Prescott, J. E. (1988). Variations in Critical Success Factors Over the Stages in the Project Life Cycle, (March). https://doi.org/10.1177/014920638801400102

Pinto, J. K., \& Slevin, D. P. (1987). Critical Factors in Successful Project Implementation, (February 1987). https://doi.org/10.1109/TEM.1987.6498856

Pinto, J. K., \& Slevin, D. P. (1988). Critical Success Factors Across the Project Life Cycle, (June 1988).

PMI. (2010). The Value of Project Management. Project Management Institution, 1-6. https://doi.org/10.13140/2.1.4695.6809

Project Management Institute. (2013). A guide to the project management body of knowledge (PMBOK ${ }^{\circledR}$ guide). Project Management Institute. https://doi.org/10.1002/pmj.20125 
Project Management Institute. (2017). Success Rates Rise, 9th Global Project Management Survey. PMI's Pulse the Profession, 32. Retrieved from http://www.pmi.org//media/pmi/documents/public/pdf/learning/thought-leadership/pulse/pulse-of-the-profession-2017.pdf

Project Management Institute. (2018). Success in Disruptive Times. Pulse of the Profession, 10th Globa, 35. Retrieved from https://www.pmi.org/learning/thought-leadership/pulse/pulse-of-the-profession-2018

Sanders, L., \& Ireland, R. (2007). Book Reviews. Research in Dance Education, 8(1), 87-95. Retrieved fromhttp://10.0.4.56/14647890701272894\%0Ahttp://search.ebscohost.com/login.aspx?direct=true \&db=a9h $\& \mathrm{AN}=24634814 \&$ site $=$ ehost-live $\&$ scope $=$ site

The Standish Group. (2013). CHAOS MANIFESTO 2013: Think Big, Act Small. The Standish Group International, 1-52. Retrieved from http://www.standishgroup.com 